\title{
Gorontalo
}

Journal of Public Health

Volume 2 - No. 2 - Oktober 2019

P-ISSN: 2614-5057, E-ISSN: 2614-5065

\section{Pengetahuan, Status Hidrasi, Persen Lemak Tubuh, Kadar Hemoglobin, dan Kebugaran Atlet Senam}

\section{Hydration Knowledge, Hydration Status, Percent Body Fat, Hemoglobin Level and Physical Fitness in Gymnastics Athletes}

\author{
Ayu Ghalda*, Nazhif Gifari, Nadiyah \\ Program Studi Gizi, Fakultas Ilmu-Ilmu Kesehatan, Universitas Esa Unggul, \\ Jakarta, Indonesia \\ *email: ayughalda@gmail.com
}

\begin{abstract}
Physical fitness is the ability of a person body to do a day work without feeling significant fatigue, that the body has a reserve of energy to overcome the excessive workload. The purpose of this study was to determine the relationship between hydration knowledge, hydration status, body composition, hemoglobin level with physical fitness in gymnastics athletes. This study was design a cross sectional study at GOR Raden Inten East Jakarta. Independent variables were hydration knowledge, hydration status, body composition (percent of body fat) and hemoglobin level, while the dependent variable was physical fitness. The statistical test used in this study was the spearman correlation test, because the dependent variable in this study was abnormally distributed. The results of this study were that there was no significant relationship between hydration knowledge and physical fitness $(r=0.181 ; p>0.05)$, there was no significant relationship between hydration status and physical fitness $(r=-0,440 ; p=0,052)$, there was no relationship significant between body composition (percent of body fat) and physical fitness $(r=0,351 ; p>0.05)$, and there was a significant relationship between hemoglobin level and physical fitness ( $r=0,600 ; p<0.05)$. The conclusion in this study, there was a significant relationship between hemoglobin level and physical fitness.
\end{abstract}

Keywords; hemoglobin, physical fitness, hydration knowledge, percent body fat, hydration status

\begin{abstract}
Abstrak
Kebugaran jasmani merupakan kemampuan tubuh seseorang untuk melakukan suatu pekerjaan sehari-hari tanpa merasakan kelelahan yang cukup berarti, sehingga tubuh itu sendiri memiliki cadangan energi untuk mengatasi beban kerja yang berlebih. Tujuan penelitian ini untuk mengetahui hubungan pengetahuan hidrasi, status hidrasi, komposisi tubuh, kadar hemoglobin dengan kebugaran pada atlet senam. Penelitian ini adalah penelitian kuantitatif dengan desain penelitian cross sectional yang dilakukan di GOR Raden Inten Jakarta Timur. Variabel independen yaitu pengetahuan hidrasi, status hidrasi, komposisi tubuh (persen lemak tubuh) dan kadar hemoglobin, sedangkan variabel dependen yaitu kebugaran. Uji statistik yang digunakan dalam penelitian ini menggunakan uji korelasi spearman, karena variabel dependen pada penelitan
\end{abstract}


berdistribusi tidak normal. Hasil dari penelitian yaitu tidak terdapat hubungan yang signifikan antara pengetahuan hidrasi dan kebugaran $(r=0,181 ; p>0,05)$, tidak terdapat hubungan yang signifikan antara status hidrasi dan kebugaran ( $\mathrm{r}$ $=-0,440 ; p>0,05)$, tidak terdapat hubungan yang signifikan antara komposisi tubuh dan kebugaran $(\mathrm{r}=0,351 ; \mathrm{p}>0,05)$ dan terdapat hubungan yang signifikan antara kadar hemoglobin dan kebugaran $(\mathrm{r}=0,600 ; \mathrm{p}<0,05)$. Kesimpulan dalam penelitian ini yaitu terdapat hubungan yang signifikan antara kadar hemoglobin dengan kebugaran atlet.

Kata kunci; hemoglobin, kebugaran, pengetahuan hidrasi, persen lemak tubuh, status hidrasi

\section{PENDAHULUAN}

Olahraga adalah serangkaian gerak yang teratur dan terencana untuk memelihara gerak dan kemampuan gerak (Giriwijoyo dan Sidik, 2013). Olahraga merupakan bagian dalam proses pembangunan Bangsa dan Negara. Sehingga perlu adanya kebijakan dalam upaya meningkatkan dan mengembangkan prestasi dibidang olahraga (Kemenpora, 2016). Untuk mencapai prestasi seorang atlet yang maksimal dalam sebuah cabang olahraga diperlukan manajemen latihan yang terbaik, termasuk dalam kebutuhan dan kecukupan gizi yang sesuai dengan jenis olahraga yang digeluti. Namun masih banyak atlet yang asupan gizinya tidak sesuai akibat kurangnya pengetahuan dan pemahaman atlet dalam memilih makanan, dan masih kurangnya edukasi gizi tentang pentingnya gizi olahraga prestasi bagi atlet (Kemenkes, 2014). Senam merupakan jenis olahraga yang membutuhkan kekuatan, kecepatan, kelenturan dan penampilan yang cantik. Salah satu penentu keberhasilan seorang atlet saat bertanding adalah kebugaran dari atlet itu sendiri.

Kebugaran seorang atlet dipengaruhi oleh beberapa faktor salah satunya yaitu yang berkaitan dengan gizi (Bryantara, 2016). Salah satu unsur penting gizi adalah air. Pengetahuan hidrasi menjadi sangat penting bagi seorang atlet, karena atlet membutuhkan pengetahuan bagaimana cara agar mampu mengganti cairan tubuhnya selama latihan atau berolahraga untuk mempertahankan status hidrasinya (Decher, 2008). Pengetahuan mampu mempengaruhi kebiasaan atau perilaku seseorang termasuk dalam konsumsi air minum. Penelitian yang dilakukan Jessri (2010) yang dilakukan kepada 264 atlet sepak bola dan basket di Amerika menunjukkan pengetahuan mengenai hidrasi sebanyak 27,3\% laki - laki dan 32,9\% perempuan mengetahui bahwa rasa haus merupakan indikator dari kebutuhan cairan, dan hanya $12 \%$ perempuan dan $8,2 \%$ laki-laki yang memiliki pengetahuan tentang jumlah asupan cairan yang diperlukan untuk memenuhi kebutuhan cairan dalam sesi latihan yang lebih dari 2 jam.

Hidrasi diartikan seimbangnya cairan dalam tubuh dan merupakan syarat penting untuk menjamin fungsi metabolisme sel tubuh. Sedangkan dehidrasi adalah kurangnya cairan dalam tubuh atau terjadinya ketidakseimbangan cairan tubuh yang disebabkan oleh tidak seimbangnya asupan dan pengeluaran dari cairan itu sendiri (Kusuma, 2016). Asupan cairan menjadi sangat penting karena persentase cairan cukup besar dari berat badan manusia. Dalam tubuh sekitar $60 \%$ dari berat badan seorang pria dan sekitar $50 \%$ dari berat badan seorang wanita. Apabila seseorang kehilangan 15\% air dari berat badannya akan mengakibatkan kematian. Nilai batas seseorang mengalami dehidrasi yang masih dapat ditoleransi yaitu $2 \%$ dari berat badan, namun kemampuan toleransi seseorang terhadap dehidrasi berbeda-beda (Hadi, 2017). Penelitian yang dilakukan Ramdhan (2016) pada atlet basket menunjukkan sebanyak $52,2 \%$ atlet mengalami dehidrasi. Hal tersebut menunjukkan status hidrasi atlet masih banyak yang kurang baik. 
Komposisi tubuh memiliki pengaruh yang cukup besar terhadap kinerja seseorang dalam berbagai olahraga. Kelebihan lemak tubuh dapat merugikan kinerja seorang atlet sedangkan massa tubuh tanpa lemak memiliki pengaruh positif dalam kinerja atlet. Begitupun dengan olahraga senam yang dimana komposisi tubuh memiliki peran yang sangat penting. Atlet senam harus memiliki kekuatan yang tinggi dan bobot tubuh yang cukup kecil (Benardot, 2014). Hal tersebut dikarenakan beberapa menyatakan bahwa berat badan yang rendah merupakan hal yang penting dalam keberhasilan pesenam pria dan wanita. Oleh karena itu pesenam banyak melakukan diet yang tidak sehat untuk menjaga bentuk tubuh yang diinginkan (Karabudak, 2016). Hasil penelitian Murbawati (2017) menunjukkan terdapat hubungan antara persen lemak tubuh dengan tingkat kesegaran jasmani.

Selain faktor-faktor diatas kebugaran atlet sangat dipengaruhi oleh kemampuan tubuh dalam mengambil oksigen untuk diedarkan ke seluruh sel yang membutuhkan oleh hemoglobin. Hemoglobin $(\mathrm{Hb})$ merupakan protein komplek yang terdiri dari heme yang mengandung besi dan globin yang merupakan alat untuk mengangkut oksigen ke sel tubuh. Hb sering digunakan menjadi indikator seseorang dalam mendeteksi penyakit anemia. Hasil Riskesdas tahun 2013 menunjukkan prevalensi anemia di Indonesia pada anak umur 5 - 14 tahun sebanyak 26,4\% dan anak 15 - 24 tahun 18,4\% (Kemenkes RI, 2013), sementara berdasarkan hasil Riskesdas tahun 2018 menunjukkan prevalensi anemia pada kelompok umur 5 - 14 tahun 26,8\% dan pada usia 15 24 tahun 32,0\% (Kemenkes RI, 2019). Hal ini menunjukkan terjadi peningkatan prevalensi anemia pada remaja. Terdapat hubungan yang signifikan antara status hemoglobin dengan daya tahan kardiorespirasi pada atlet (Anggraeni dan Wirjatmadi, 2019). Kondisi anemia (rendah konsentrasi $\mathrm{Hb}$ ) akan berkorelasi negatif dengan performa seorang atlet, karena kondisi tersebut dapat menurunkan kapasitas $\mathrm{Hb}$ dalam mengangkut oksigen yang pada akhirnya dapat menurunkan performa atlet.

Prestasi yang optimal seorang atlet dalam sebuah cabang olahraga diperlukan manajemen latihan yang terbaik, yang didukung oleh kebugaran atlet yang sesuai dengan jenis olahraga yang digeluti. Kebugaran atlet sangat berpengaruh terhadap performa atlet, sehingga penelitian ini bertujuan untuk mengetahui sejumlah faktor yang mempengaruhi status kebugaran pada atlet.a.

\section{METODE}

Jenis penelitian ini kuantitatif dengan rancangan penelitian cross sectional, karena peneliti mengambil data variabel independen (pengetahuan hidrasi, status hidrasi, persen lemak tubuh, dan kadar hemoglobin) dan variabel dependen (kebugaran berdasarkan $\mathrm{VO}_{2}$ max) dalam waktu yang bersamaan. Penelitian ini dilakukan di GOR Raden Inten Jakarta Timur, yang dilakukan pada bulan Januari - Februari 2019. Sampel dalam penelitian ini yaitu keseluruan populasi atlet senam remaja berusia 10-18 tahun yang berjumlah 20 orang di GOR Raden Inten Jakarta Timur.

Data primer dalam penelitian ini menggunakan kuesioner yang didalamnya berisi pertanyaan-pertanyaan untuk menjawab pengetahuan hidrasi, pengukuran antropometri tinggi badan menggunakan microtoise, berat badan dan persen lemak tubuh menggunakan Bioelectrical Impedance Analysis (BIA), berat jenis urin untuk pengukuran status hidrasi, dan kadar hemoglobin menggunakann hemoglobinometer digital (GCHB Easy Touch). Data sekunder dalam penelitian ini yaitu data flexibility yang menjadi karakteristik responden dan $\mathrm{VO}_{2}$ max yang menjadi data kebugaran yang dianalisis dalam penelitian ini, data tersebut diperoleh dari tim SC (Strength and Conditioning) dari PPOP dan Pelatda DKI Jakarta. 
Data yang terkumpul kemudian diolah dan dianalisis menggunakan komputer. Analisis univariat digunakan untuk mendeskripsikan setiap variabel yang diteliti. Variabel yang diteliti dalam penelitian ini yaitu umur, jenis kelamin, cabang senam, flexibility, pengetahuan hidrasi, status hidrasi, persen lemak tubuh, kadar hemoglobin, dan kebugaran berdasarkan $\mathrm{VO}_{2}$ max. Pengukuran status hidrasi menggunakan berat jenis urin (BJU). Analisis bivariate dijelaskan dengan menggunakan uji rank-spearman untuk melihat hubungan pengetahuan hidrasi, status hidrasi, persen lemak tubuh, kadar hemoglobin, dan kebugaran atlet senam.

\section{HASIL DAN PEMBAHASAN}

\section{Analisis Karakteristik Subjek Penelitian}

Responden dalam penelitian ini adalah atlet senam remaja di GOR Raden Inten yang berjumlah 20 orang. Karakteristik responden dalam penelitian ini yaitu jenis kelamin, umur, status gizi, jenis cabang olahraga, dan hasil tes flexibility. Hasil distribusi responden menurut jenis kelamin, umur, status gizi, jenis cabang olahraga, dan tes flexibility ditunjukkan pada Tabel 1 dan Tabel 2.

Tabel 1. Karakteristik Data Jenis Kelamin, Status Gizi dan

\begin{tabular}{ccc}
\multicolumn{2}{c}{ Cabang Senam Responden penelitian } \\
\cline { 2 - 3 } Variabel & $\mathrm{n}$ & Jumlah \\
\cline { 2 - 3 } & & \\
\hline Jenis Kelamin & 5 & 25,0 \\
$\quad$ Laki-laki & 15 & 75,0 \\
$\quad$ Perempuan & & \\
Status Gizi & & 10,0 \\
$\quad$ Kurus & 18 & 90,0 \\
$\quad$ Normal & & \\
Cabang Senam & & 40,0 \\
$\quad$ Ritmik & 12 & 60,0 \\
$\quad$ Artistik & 20 & 100 \\
\hline Total & 20
\end{tabular}

Berdasarkan Tabel 1, dapat diketahui bahwa distribusi jenis kelamin dalam penelitian ini yaitu atlet perempuan lebih banyak yakni $75,0 \%$ dibandingkan dengan atlet laki - laki yakni hanya $25,0 \%$. Analisis status gizi menunjukkan sebagian besar atlet memiliki status gizi normal yakni 90,0\%. Analisis cabang senam menunjukkan $60,0 \%$ cabang senam artistik dan $40,0 \%$ cabang senam ritmik.

Tabel. 2 Karakteristik Umur, Flexibility, Pengetahuan Hidrasi, Status Hidrasi, Persen Lemak Tubuh, Kadar Hemoglobin dan $\mathrm{VO}_{2}$ max Responden Penelitian

\begin{tabular}{lccc}
\hline \multicolumn{1}{c}{ Variabel } & $\mathrm{n}$ & Median & $\mathrm{SE}$ \\
\hline Umur (tahun) & 20 & 13,5 & 0,475 \\
Flexibility (cm) & 20 & 47,5 & 2,501 \\
Pengetahuan Hidrasi & 20 & 90,0 & 1,701 \\
Status Hidrasi (g/dl) & 20 & 1,015 & 1,593 \\
Persen Lemak Tubuh (\%) & 20 & 15,9 & 1,128 \\
Kadar Hemoglobin (gr/dl) & 20 & 13,84 & 2,070 \\
$\mathrm{VO}_{2}$ max (ml/kgBB) & 20 & 43,57 & 0,998 \\
\hline
\end{tabular}

Berdasarkan Tabel 2 diketahui bahwa median umur yaitu 13,5 tahun dengan standar error 0,475, median flexibility yaitu 47,5 cm dengan standar error 2,501, median pengetahuan hidrasi 90 dengan standar error 1,701, median status hidrasi yaitu $1,015 \mathrm{~g} / \mathrm{dl}$ dengan standar error 1,593, median persen lemak tubuh yaitu $15,9 \%$ dengan standar error 1,128 , median kadar hemoglobin yaitu $13,84 \mathrm{gr} / \mathrm{dl}$ dengan standar error 2,070 gr/dl dan median kebugaran berdasarkan $\mathrm{VO}_{2} \max 43,57 \mathrm{ml} / \mathrm{kgBB}$ dengan standar error 0,998. 


\section{Pengetahuan, Status Hidrasi, Persen Lemak Tubuh dan Kadar Hemoglobin Hubungannya dengan Kebugaran Atlet}

Menurut Notoatmodjo (2003) pengetahuan merupakan hasil dari proses pembelajaran. Hasil data yang diperoleh dalam penelitian ini menunjukkan bahwa rata-rata nilai pengetahuan hidrasi dari responden yaitu 85 yang apabila dikategorikan termasuk dalam kategori berpengetahuan yang baik. Pengetahuan menjadi aspek penting yang dapat mempengaruhi tindakan seseorang, perilaku yang tidak didasarkan pada pengetahuan dan kesadaran biasanya perilaku tersebut tidak akan bertahan lama. Pengetahuan hidrasi yang baik dapat membuat seseorang paham agar dapat menjaga keadaan hidrasi tubuhnya tetap terjaga. Pengetahuan dapat diperoleh melalui pendidikan formal maupun non formal, selain itu juga dapat diperoleh dengan melihat, mendengar, atau melalui media social. Tabel 3 menunjukkan hubungan status hidrasi, pengetahuan hidrasi, persen lemak tubuh, kadar hemoglobin dengan kebugaran atlet.

Tabel 3. Hubungan Status Hidrasi, Pengetahuan Hidrasi, Persen Lemak Tubuh, Kadar Hemoglobin dengan Kebugaran Atlet

\begin{tabular}{lcc}
\hline \multicolumn{1}{c}{ Variabel } & Korelasi $(\mathrm{r})$ & $\mathrm{p}$-Value \\
\hline Pengetahuan hidrasi & 0,181 & 0,445 \\
\hline Status hidrasi & $-0,440$ & 0,052 \\
\hline Persen lemak tubuh & 0,351 & 0,129 \\
\hline Kadar hemoglobin & 0,600 & 0,005 \\
\hline
\end{tabular}

Berdasarkan hasil uji korelasi spearman rho pada Tabel 3 dapat diketahui bahwa tidak terdapat hubungan yang signifikan antara pengetahuan hidrasi dan kebugaran berdasarkan nilai $\mathrm{VO}_{2}$ max, hal tersebut ditunjukkan dengan $p$ value $=0,445$. Hasil uji korelasi tersebut menunjukkan nilai $r=0,181$ dengan pola positif atau searah yang berarti semakin tinggi pengetahuan maka nilai kebugaran berdasarkan $\mathrm{VO}_{2}$ max akan menuju kearah yang tinggi. Penelitian ini didukung oleh Maemun (2017) yang melakukan penelitian pada atlet rugby UNJ menunjukkan bahwa pengetahuan hidrasi dan kebugaran tidak memiliki hubungan yang signifikan ( $p=0,380)$.

Pengetahuan hidrasi tidak berhubungan dengan kebugaran karena pengetahuan yang baik belum tentu akan diimbangi penerapan pengetahuan tersebut kedalam kehidupan sehari-hari, sehingga tidak terjadi adanya perubahan perilaku. Seorang atlet yang memiliki pengetahuan baik belum tentu kebugarannya akan baik karena belum tentu pengetahuan yang dimilikinya akan diterapkan untuk melakukan upaya-upaya dalam peningkatan kebugaran. Pengetahuan hidrasi yang baik harus diimbangi dengan kesadaran akan pentingnya hidrasi, karena jika seseorang hanya tahu tetapi tidak melakukan tindakan untuk mempertahankan kondisi hidrasinya akan menimbulkan penurunan konsentrasi, cepat mengalami kelelahan dan dapat menurunkan prestasi atlet (Fachri, 2017).

Status hidrasi merupakan suatu kondisi atau keadaan yang menggambarkan jumlah cairan dalam tubuh yang dapat diketahui oleh beberapa pengujian status hidrasi contohnya dengan pengujian warna urin (Ramdhan, 2016). Berdasarkan hasil uji korelasi spearman rho pada Tabel 3 dapat diketahui bahwa tidak terdapat hubungan yang signifikan antara status hidrasi berdasarkan berat jenis urin dengan kebugaran berdasarkan nilai $\mathrm{VO}_{2}$ max, hal tersebut ditunjukkan dengan nilai $p$ value $=0,052$. Hasil uji korelasi tersebut menunjukkan nilai $r=-0,440$ dengan pola negatif atau tidak searah yang berarti semakin nilai berat jenis urin responden maka nilai kebugaran berdasarkan $\mathrm{VO}_{2}$ max akan menuju kearah yang rendah. 
Sejalan dengan penelitian yang dilakukan oleh Rahmawati dkk (2017) pada atlet voly putri menunjukkan tidak adanya hubungan yang signifikan antara status hidrasi dan kebugaran dengan nilai $p$ value sebesar 0,515. Nilai koefisien korelasi yang diperoleh yaitu $r=-0,190$ menunjukkan antara variabel memiliki kekuatan hubungan yang lemah. Namun penelitian ini tidak sejalan dengan penelitian yang dilakukan Rahmaniar dan Dewi (2018) pada atlet bola basket remaja yang menunjukkan bahwa adanya hubungan yang signifikan antara status hidrasi dan kebugaran, dalam penelitian ini didapat hasil $p=$ 0,050 dan $r=0,265$, yang berarti apabila status hidrasi semakin baik, maka tingkat kebugaran akan semakin baik juga.

Air merupakan komponen tubuh yang penting, sekitar 55-60\% dari berat badan orang dewasa, tubuh tidak dapat bertahan lama tanpa air. Keseimbangan metabolisme dalam tubuh sangat penting saat berolahraga dan air dapat menjamin metabolisme dalam tubuh itu sendiri (Murray, 2007). Kehilangan air 4\% dari tubuh mengakibatkan otot kehilangan kekuatan dan ketahanan, saat kehilangan 10-12\% air tubuh akan mengalami kematian (Hampl, 2007). Memiliki tingkat hidrasi yang baik dapat membuat air melakukan fungsinya dengan sebagaimana mestinya, salah satunya yaitu membawa oksigen dari paru-paru menuju seluruh tubuh (katalisator). Sehingga metabolisme dalam tubuh dapat berjalan lancar dan dapat mendukung kemampuan daya tahan atlet saat berlatih maupun bertanding (Pratama dan Cerika, 2018).

Faktor antropometri dalam olahraga sangat diperlukan dalam menunjang prestasi seorang atlet, seperti yang dikatakan Indrianti (2010) peran antropometri di dalam olaharaga beragam yaitu mulai dari menentukan cabang olahraga yang dapat memaksimalkan kondisi atlet, status kebugaran, komposisi lemak, tulang, ukuran tubuh, kadar air, dan massa otot. Berdasarkan hasil uji korelasi spearman rho pada Tabel 3 dapat diketahui bahwa tidak terdapat hubungan yang signifikan antara persen lemak tubuh dan kebugaran berdasarkan nilai $\mathrm{VO}_{2}$ max, hal tersebut ditunjukkan dengan $p$-value $=0,129$. Hasil uji korelasi tersebut menunjukkan nilai $r=0,351$ dengan pola positif atau searah yang berarti semakin tinggi persen lemak tubuh maka nilai kebugaran berdasarkan $\mathrm{VO}_{2}$ max akan menuju kearah yang tinggi. Hasil penelitian ini tidak sejalan dengan hasil penelitian pada Remaja Putri di Semarang yang menunjukkan terdapat hubungan persen lemak tubuh dengan tingkat kebugaran jasmani (Murbawani, 2017).

Tidak adanya hubungan antara persen lemak tubuh dan kebugaran dalam penelitian ini bisa terjadi karena rata-rata persen lemak tubuh dari atlet masih dalam batas normal. Hubungan persentase lemak tubuh dengan kebugaran dapat terjadi apabila terjadi kelebihan lemak tubuh yang akan meningkatkan massa tubuh sehingga akan menyebabkan kemampuan bergerak menurun. Tubuh dengan lemak yang berlebih dapat menyebabkan kelelahan yang lebih cepat, oleh karena itu dengan komposisi lemak tubuh yang tinggi maka suhu tubuh akan meningkat lebih banyak sehingga tubuh akan lebih mudah mengalami kelelahan.

Persen lemak tubuh bukan merupakan satu-satunya faktor yang mempengaruhi kebugaran seorang atlet. Faktor lain diantaranya keturunan, gaya hidup, asupan zat gizi, latihan, jenis kelamin, usia, program latihan yang terorganisir yang tidak diukur dalam penelitian ini dapat menjadi salah satu faktor yang mempengaruhi kebugaran dari atlet senam.

Hemoglobin merupakan senyawa yang mampu mengikat oksigen dan membawa oksigen dari paru-paru untuk diedarkan dan dibagikan ke seluruh sel di berbagai jaringan. Sehingga jumlah hemoglobin dalam sel darah merah sangat penting, semakin banyak oksigen yang dapat diikat dan dibawa oleh sel darah sehingga pasokan oksigen ke berbagai sel tubuh dapat terpenuhi dengan 
begitu berbagai sel dalam tubuh dapat bekerja melakukan fungsinya dengan baik.

Berdasarkan hasil uji korelasi spearman rho pada Tabel 3 dapat diketahui bahwa terdapat hubungan yang signifikan antara kadar hemoglobin dan kebugaran berdasarkan nilai $\mathrm{VO}_{2}$ max, hal tersebut ditunjukkan dengan $p$ value $=0,005$. Hasil uji korelasi tersebut menunjukkan nilai koefisien korelasi $r=$ 0,600 dengan pola positif yang berarti semakin tinggi kadar hemoglobin maka nilai kebugaran berdasarkan $\mathrm{VO}_{2}$ max akan menuju ke arah yang tinggi. Sejalan dengan penelitian yang dilakukan oleh Mustaqim dan Endang (2013) kepada siswa ekstra kulikuler sepakbola menunjukkan bahwa adanya hubungan yang signifikan antara kadar hemoglobin dan kebugaran $(r=0,710 ; p=0,001)$. Penelitian ini juga sejalan dengan penelitian yang dilakukan oleh Mahastuti dkk (2018) kepada atlet bola basket menunjukkan ada hubungan yang signfikan antara kadar hemoglobin dan kebugaran $(r=0,693 ; p=0,001)$. Demikian juga dengan hasil penelitian pada atlet Unit Kegiatan Mahasiswa bola basket yang menyatakan terdapat hubungan yang signifikan antara status hemoglobin dengan daya tahan kardiorespirasi $\left(\mathrm{VO}_{2} \max\right.$ ) pada atlet (Anggreani dan Wirjatmadi, 2019).

Penelitian ini menunjukkan adanya hubungan antara kadar hemoglobin dan kebugaran berarti sesuai dengan teori, karena fungsi dari hemoglobin yang membantu dalam proses pengangkutan oksigen ke seluruh tubuh, semakin baik kadar hemoglobin maka akan semakin baik proses pengangkutan oksigen tersebut ke seluruh tubuh. Pentingnya kelancaran proses pengangkutan oksigen keseluruh tubuh disebabkan beberapa jaringan tubuh membutuhkan oksigen dalam jumlah besar. Bila jumlah oksigen yang dipasok berkurang maka akan menurunkan kinerja dari organ tersebut.

Pada saat melakukan aktivitas fisik yang intens, terjadi peningkatan kebutuhan oksigen oleh otot yang sedang bekerja. Untuk dapat memasok kebutuhan oksigen yang adekuat maka diperlukan paru-paru yang berfungsi dengan baik, termasuk kapiler, dan pembuluh darahnya. Seorang atlet yang sudah biasa melakukan latihan, konsumsi oksigen akan meningkat 20 kali pada saat melakukan latihan intensitas maksimal. Selain itu di dalam sistem energi daya tahan sangat dipengaruhi oleh pasokan oksigen untuk dialirkan keseluruh tubuh yang membantu dalam proses pembentukan energi siap pakai atau ATP di dalam tubuh. Sehingga daya tahan sangat dipengaruhi oleh kemampuan seseorang dalam mengambil oksigen yang dibutuhkan oleh tubuh.

\section{PENUTUP}

Disimpulkan bahwa pengetahuan hidrasi, status hidrasi dan persen lemak tubuh tidak berhubungan dengan kebugaran atlet, sementara kadar hemoglobin dapat mempengaruhi kebugaran pada atlet senam, jika atlet senam memiliki kadar hemoglobin yang semakin tinggi maka kebugaran akan semakin baik atau tinggi pula.

\section{UCAPAN TERIMA KASIH}

Terima kasih kepada Pimpinan Pusat Pelatihan Olahraga Pelajar (PPOP) Ragunan, Jakarta dan para atlet gymnastik yang telah berpatisipasi dalam penelitian ini.

\section{DAFTAR PUSTAKA}

Anggraeni L dan Wirjatmadi RB. 2019. Status Hemoglobin, Kebiasaan Merokok dan Daya Tahan Kerdiorespirasi $\left(\mathrm{VO}_{2}\right.$ maks) pada Atlet Unit Kegiatan Mahasiswa Bola Basket. Media Gizi Indonesia. 14(1): 27 - 34. 
Bernadot D. 2014. Gymnastics In W. Blackwell Sport Nutrition (pp. 596-606). Medical Commision Publication. New Delhi.

Bryantara OF. 2016. Faktor yang Berhubungan dengan Kebugaran Jasmani (VO2 Maks) Atlet Sepak Bola. Jurnal Berkala Epidemiologi. 237-249.

Decher NR, Yeargin A, Douglas C, Susan WY. 2008. Hydration Status, Knowledge and Behavior in Youth at Summer Sports Camps. International Journal of Sports Physiology and Performance. 3(3): 262-278.

Fachri RL. 2017. Pengetahuan Tentang Kesdaran Hidrasi Pada Atlet Sepakbola SSB Hizbul Wathan U-17 Kecamatan Babat Kabupaten Lamongan. (Skripsi). Universitas Negeri Surabaya. Surabaya.

Giriwijoyo S dan Sidik DZ. 2013. Imu Kesehatan Olahraga. PT Remaja Rordakarya. Bandung.

Hadi NS. 2017. Air Dalam Hardinsyah dan Supariasa ID. Imu Gizi Teori dan Aplikasi (pp. 99-105). EGC. Jakarta.

Hampl J dan Garrdlaw G. 2007. Perspective in Nutrition Seventh Edition. McGraw-Hill. New York.

Indrianti E. 2010. Antropometri untuk Kedokteran, Keperawatan, Gizi, dan Olahraga. PT. Citra Aji Parama. Yogyakarta.

Jessri M, Maryam J, Bahram R, Caryn Z. 2010. Evaluation of Iranian College Athletes Sports Nutrition Knowledge. International Journal of Sports Nutrition and Exercise Metabolism. 20: 257-263.

Karabudak E, Eda K, Yasemin E, Ozge K. 2016. Dietary Intake of Turkish Gymnast and Non-Gymnast Children. Nutrition and Dietetics. 73: 184-189.

Kemenkes RI. 2014. Pedoman Gizi Olahraga Prestasi. Kementrian Kesehatan RI: Jakarta.

Kemenkes RI. 2013. Hasil Riset Kesehatan Dasar (Riskesdas) 2013. Jakarta. Kemenkes RI.

Kemenkes RI. 2019. Laporan Nasional Riskesdas 2018. Jakarta. Lembaga penerbit badan penelitian dan pengembangan kesehatan.

Kemenpora RI. 2016. Laporan Kinerja Kementrian Pemuda dan Olahraga Republik Indonesia. Kementrian Pemuda dan Olahraga. Jakarta.

Kusuma RD, Agustina ATT, Syarifah NYR. 2016. Hubungan Tingkat Pengetahuan Asupan Cairan terhadap Status Hidrasi pada Lansia di Posyandu Lansia Keluarahan Banjar Serasan Kecamatan Pontianak Timur. Jurnal Cerrebellum. 360-370.

Maemun P. 2017. Pengetahuan tentang Cairan, Asupan Cairan, Status Hidrasi, Status Gizi, Aktifitas Fisik, dan Tingkat Kebugaran Fisik Pada Atlet Rugby di Universitas Negeri Jakarta. (Skripsi). Universitas Esa Unggul. Jakarta.

Mahastuti F, Zen R, Suroto. 2018. Hubungan Tigkat Kecukupan Gizi, Aktifitas Fisik, dan Kadar Hemoglobin dengan Kebugaran Jasmani (Studi pada Atlet Basket di Universitas Negeri Semarang). Jurnal Kesehatan Masyarakat. 458-466.

Murbawani EA. 2017. Hubungan Persen Lemak Tubuh dan Aktivitas Fisik dengan Tingkat Kesegaran Jasmani Remaja Putri. Journal of Nutrition and Health. 5(2): $69-84$.

Murray B. 2007. Hydration and Physical Performance. Journal of the American College of Nutrition. 542-548.

Mustaqim EY dan Endang SW. 2013. Hubungan Kadar Hemoglobin (Hb) dengan Kebugaran Jasmani Pada Siswa Ekstrakulikuler Sepakbola SMA Negeri 1 Bangsal. Jurnal Pendidikan Olahraga dan Kesehatan. 637-640.

Notoatmodjo S. 2003. Pendidikan dan Perilaku Kesehatan. Rineka Cipta. Jakarta.

Pratama AWP dan Cerika R. 2018. Hubungan Status Hidrasi dengan $\mathrm{VO}_{2} \max$ Pada Atlet Sepak Bola. Medikora. 61-72. 
Rahmaniar A dan Dewi RC. 2018. Tingkat Konsumsi Karbohidrat, Status Hidrasi Serta Cairan Pada Atlet Bola Basket. Medikora. 53-61.

Rahmawati, Nur H, Setyowati. 2017. Hubungan Asupan Energi dan Status Hidrasi dengan Kebugaran Atlet Voly Putri Club Voly Baja 78 Bantul Yogyakarta. Jurnal Gizi Poltekkes Kemenkes Yogyakarta. 56-60

Ramdhan RI dan Rismayanti C. 2016. Hubungan Antara Status Hidrasi Serta Konsumsi Cairan Pada Atlet Bola Basket. Medikora. 53-61. 